\title{
The influence of the dissolved oxygen concentration on the physiology and ecology of Sphaerotilus natans Kütz
}

\author{
Kl. Mechsner \\ Swiss Federal Institute of Technology Zürich and Federal Institute for Water Resources and Water Pollution Control, \\ $\mathrm{CH}-8600$ Dübendorf, Switzerland
}

Summary. Using a hermetically closed experimental system the influence of continuously decreasing oxygen concentration on the metabolism of Sphaerotilus natans was investigated by concurrently measuring the temperature, $\mathrm{pH}$, oxygen, sucrose, organic acids, diluted organic carbon (DOC) and dry weight.

Oxygen and sucrose were eliminated linearly until the detection limit of $<0,1 \mathrm{mg} \mathrm{O}_{2} / 1$ for dissolved oxygen concentration was reached. Under anaerobic conditions neither sucrose uptake nor organic acid formation occured and autolytic processes were evident. The results confirm that Sphaerotilus natans is an aerobic organism with no capacity for fermentative metabolism.

\section{Introduction}

Sphaerotilus natans, one of the most important indicator organisms for polluted water, assumes a substantial ecological significance by causing a nuisance by its frequent mass development in both polluted natural waters and in sewage treatment plants. The ecological factors that primarily influence the development of the organisms such as substrate availability (Heukelekian and Ingols 1940; Ruchoft and Kachmar 1941; Harrison and Heukelekian 1958; Mulder 1964; Pipes 1967; Adamse 1966/1968; Phaup 1968; Curtis 1969; Mechsner and Wuhrmann 1974; Roberts 1977) and light (Favre 1975; Mechsner, unpublished results) have been comprehensively investigated. However, the question of the oxygen demand of Sphaerotilus natans has received little attention. Preferential surface growth of the bacterium in laboratory culture demonstrates its aerobic character but indications of anaerobic growth by Sphaerotilus natans (Heukelekian and Ingols 1940) have been reported but never independently confirmed. Many authors emphasis the ability of Sphaerotilus natans to grow at low dissolved oxygen concentrations $\left(0,1-2 \mathrm{ppmO}_{2}\right)$ and to successfully compete with saprophytes under conditions of low dissolved oxygen concentration in the natural surface waters and in sewage treatment plants (Ruchoft and Kachmar 1941, Stokes 1954, Gaufin and Tarzwell 1956, Phaup 1968, Curtis 1969, Barnard 1978).

This communication deals with experiments designed to answer the questions, whether respiration and/or substrate uptake by Sphaerotilus natans are affected by decreasing dissolved oxygen concentrations and whether the oxidative metabolism of Sphaerotilus natans is replaced by fer- mentative processes under conditions where oxygen depletion occurs. Using a hermetically sealed experimental system it was possible to establish a continuously decreasing oxygen partial pressure as a result of the respiration of the suspended organism and to investigate the above mentioned problemes by quantitatively measuring relevant parameters.

\section{Methods \\ Organism: Sphaerotilus natans Kütz}

Isolation and culture. Naturally occuring Sphaerotilus natans flocs from model flowing water channels were rinsed with sterile buffer solution and ground by vigorous shaking with sterile quartz sand. The suspensions were increasingly diluted and plated on the following medium: peptone $0,1 \mathrm{~g}$, lactic acid $0,5 \mathrm{~g}$, gelatine $150 \mathrm{~g}$ per liter of $\mathrm{m} / 150$ phosphate buffer (ph 8,0). Incubation at $22^{\circ} \mathrm{C}$ followed. The outer filaments of the colonies were cut off and reinoculated. This procedure were repeated until the isolated colonies were no longer contaminated with other organisms. Freshly isolated Sphaerotilus natans strains are cultured and maintained at $22^{\circ} \mathrm{C}$ in $200 \mathrm{ml}$-Erlenmeyer-flasks containing $50 \mathrm{ml}$ of the following substrate solution: peptone $1 \mathrm{~g}$, sucrose $^{1} 1 \mathrm{~g}$, trace metal solution $1 \mathrm{ml}$ per liter of $\mathrm{m} / 150$ phosphate buffer (pH 8,0).

Experimental substrate. $25 \mathrm{mg} \mathrm{MgSO}_{4}, 15 \mathrm{mg} \mathrm{CaCl}_{2}$, $30 \mathrm{mg} \mathrm{NH} \mathrm{Cl}^{2}, 100 \mathrm{mg}$ sucrose ${ }^{2}, 1 \mathrm{ml}$ tracemetal solution.

Inoculum. To prepare the inoculum for the experiment, Sphaerotilus natans was precultured for $24 \mathrm{~h}$ at $25^{\circ} \mathrm{C}$ in a flask with a magnetic stirrer $(750 \mathrm{rpm})$, harvested by centrifugation and washed in sterilized beakers and resuspended in the reaction vessel so as to give a concentration of $50-100 \mathrm{mg} / \mathrm{l}$ on a dry weight basis.

Reaction vessel, (Fig. 1) 21 double wall fermenter "Schmizo" (M. Schmid, CH-4800 Zofingen) with flanged lid, O-ring gasket and fixing ring. The screw capped Sovirel SVL fittings in the lid were closed either by diaphragms (Fig. 1.1) or by a rubber bladder (Fig. 1.2 a) connected to

1 To inhibit degeneration of the organisms either carbohydrates or lactic acid are required.

$21,000 \mathrm{mg}$ sucrose and $150 \mathrm{mg} \mathrm{NH}_{4} \mathrm{Cl}$ for preculture. 


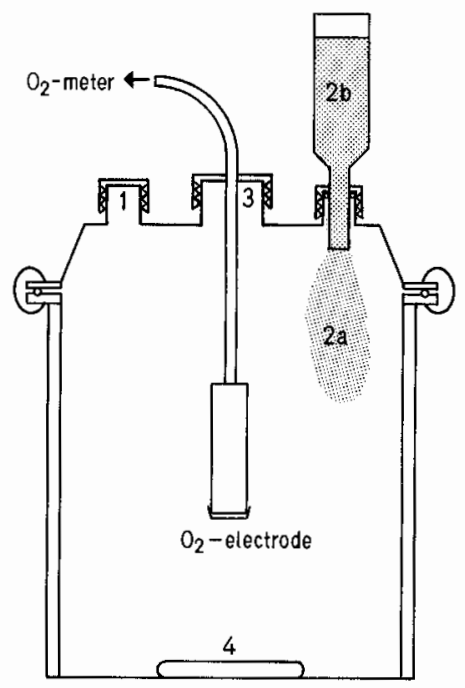

Fig. 1. Reaction vessel (explantation see text)

a column (Fig. 1.2b). Both the bladder and the column were filled with oxygen free water to balance volume differences caused by sampling. The oxygen electrode (YSI 5739) connected with the oxygen-meter (Yellow Spring Inst., Mod. 54, U.S.A.) was introduced through a gastight gasket in the central fitting (Fig. 1.3). The contents were magneticly stirred. The medium and the vessel were sterilized by autoclaving at $120^{\circ} \mathrm{C}$ for $20 \mathrm{~min}$ and the oxygen electrode was treated with $96 \%$ ethanol, rinsed with sterile water and pasteurized for $5 \mathrm{~min}$ at $75^{\circ} \mathrm{C}$ in a water bath. The temperature for the experiment was maintained at $24.5 \pm 0.5^{\circ} \mathrm{C}$ by putting the vessel in a water bath. The buffer capacity of the medium was sufficient to keep the $\mathrm{pH}$ at 6.9 .

Analysis. The dry weight was determined by membrane filtration of the bacterial suspensions and subsequent drying of the residue for $1 \mathrm{~h}$ at $103^{\circ} \mathrm{C}$. The carbon content of the dry matter was measured using a " $\mathrm{F}+\mathrm{M}$ " CHN Analyzer Mod. 185. It varied between $48 \%$ and $51 \%$ and was assumed to be $50 \%$ for calculating the substrate balances.

The sucrose was measured enzymatically, using the Bergmeyer method, adapted by Ruchti and Kunkler (1966). Organic acids were analysed by capillary gaschromatography after esterification (Gloor and Leidner 1976).

Experimental. The reaction vessel was $90 \%$ filled with substrate and aerated until oxygen saturation was reached. After addition of the inoculum $(10 \mathrm{ml})$ the vessel was completely filled with oxygen-saturated substrate and the Sovirel caps carefully closed preventing any gas bubbles. By connecting the dissolved-oxygen meter with a recorder, the oxygen uptake was followed continuously. Samples for $\mathrm{pH}$, dry weight and substrate concentration were taken with a syringe every $30 \mathrm{~min}$, immediately membrane filtered (Nuclepore PC membranes, pore size $0,4 \mu \mathrm{m}$ ) and stored for analysis at $-25^{\circ} \mathrm{C}$.

Results. The course of the experiment is shown in Fig. 2. The carbon balances (Table 1) established at the start, direct after exhaustion of the oxygen and at the end of the experiment after $24 \mathrm{~h}$ indicate that, very largely, the sub-

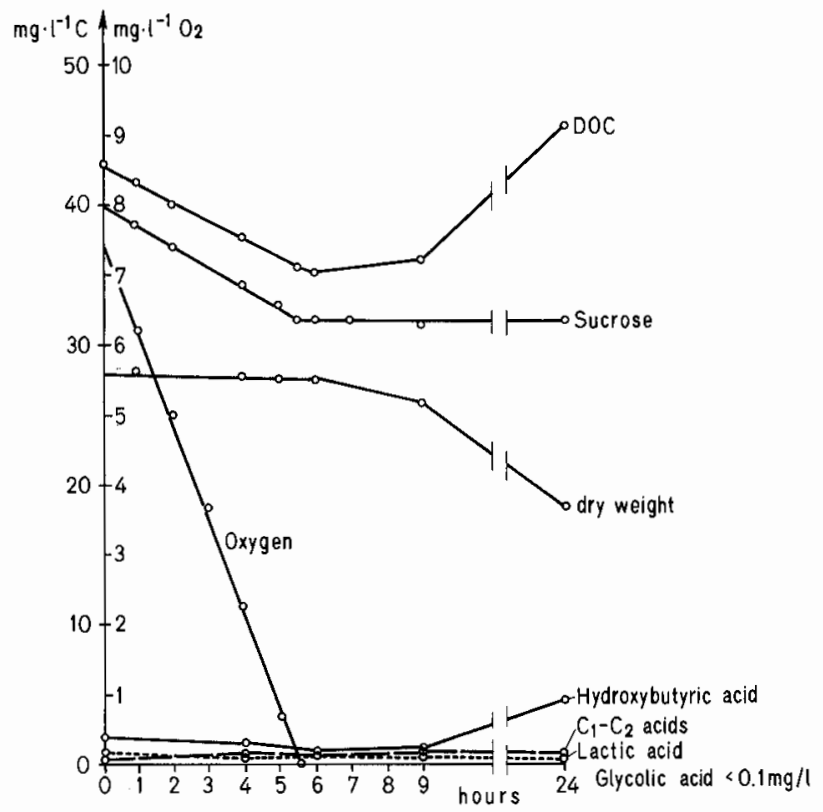

Fig. 2. Metabolic activity of Sphaerotilus natans during a decrease in oxygen concentration. All analytical data - incl. dry weight - reduced to organic carbon. Elimination rates, oxygen: $26,6 \mathrm{mg}$ $\underset{\mathrm{h}^{-1}}{\mathrm{O}_{2}} \cdot \mathrm{g} \mathrm{dry} \mathrm{weight}^{-1} \cdot \mathrm{h}^{-1}$; sucrose $: 59,7 \mathrm{mg} \mathrm{sucr} \cdot \mathrm{g}$ dry weight ${ }^{-1}$.

Table 1. Balance of medium components during the several stages of the experiment. All data reduced to $\mathrm{mg}$ org. $\mathrm{C} / 1$, DOC: diluted org. C

\begin{tabular}{|c|c|c|c|}
\hline $\begin{array}{l}\text { Sam- } \\
\text { pling }_{\text {time }}\end{array}$ & DOC & Identified Components & $\begin{array}{l}\text { Dry } \\
\text { weight }\end{array}$ \\
\hline \multirow[t]{2}{*}{ Start } & & $\begin{array}{l}\text { 39.7 Sucrose } \\
1.8 \text { Hydroxybutyric acid } \\
0.7 \text { Lactic acid } \\
0.1 \text { Glycolic acid } \\
0.3 \mathrm{C}_{1}-\mathrm{C}_{2} \text { acids }\end{array}$ & \\
\hline & 42.9 & $\overline{42.6}$ & 28.0 \\
\hline \multirow[t]{2}{*}{$\begin{array}{l}6 \mathrm{~h} \\
\text { (oxygen } \\
\text { exhaust- } \\
\text { ed) }\end{array}$} & & $\begin{array}{l}\text { 32.1 Sucrose } \\
0.8 \text { Hydroxybutyric acid } \\
1.0 \text { Lactic acid } \\
0.1 \text { Glycolic acid } \\
0.7 \mathrm{C}_{1}-\mathrm{C}_{2} \text { acids }\end{array}$ & \\
\hline & 35.05 & $\overline{34.7}$ & 27.5 \\
\hline $24 \mathrm{~h}$ & 45.7 & $\begin{array}{l}\text { 32.4 Sucrose } \\
4.9 \text { Hydroxybutyric acid } \\
0.5 \text { Lactic acid } \\
\frac{0.8}{38.6} \mathrm{C}_{1}-\mathrm{C}_{2} \text { acids } \\
+\quad 9.5 \text { Autolysis (dry weight) } \\
-\frac{3.1}{45.0} \text { Increase Hydroxybutyric acid }\end{array}$ & 18.5 \\
\hline
\end{tabular}

strate components, products and intermediates were accounted for. The respiration rate, $-26 \mathrm{mg} \mathrm{O}_{2} / \mathrm{g}$ dry weight . $\mathrm{h}$, remained constant until the detection limit of $0,05 \mathrm{mg}$ $\mathrm{O}_{2} / 1$ was reached and corresponded with values which had been obtained earlier with manometric measurements. Parallel with the respiration, the uptake of the sucrose followed 
an unlimited course as long as oxygen could be detected. No intermediates, indicative for fermentative metabolism, could be detected. Throughout the experiment, organic acids, with exception of $\beta$-hydroxybutyric acid, could only be identified in insignificant traces. $\beta$-Hydroxybutyric acid can be assumed to be an autolytic product of Sphaerotilus natans produced from its main storage material, poly- $\beta$ hydroxybutyric acid, as its appearance correlated with the decay of biomass as indicated by a reduction in the dry weight.

The increased cell lysis as soon as oxygen is exhausted completes the interpretation of the results, proving Sphaerotilus natans to be a strict aerobic organism unable to perform any fermentative metabolism in order to grow anaerobicly. However, the low critical oxygen concentration for Sphaerotilus natans, i.e., less than $0,1 \mathrm{mg} \mathrm{O}_{2} / 1$, enable the organism to grow under microaerobic conditions. This capacity is of great ecological relevance and has to be interpreted in the light of the concepts discussed by Dias et al. (1968), who suggested the reason for the positive effect of low oxygen concentration on Sphaerotilus natans development in natural mixed systems was a competitive advantage with respect to other heterotrophes resulting from a higher affinity for oxygen.

Acknowledgments. I thank Prof. Dr. K. Wuhrmann and Prof. Dr. G. Hamer for discussion of the results and advice in the preparation of the manuscript and Mr. P. Egli for technical assistance.

\section{References}

Adamse AD (1966) Bacteriological Studies an Dairy Waste Activated Sludge. Medel. Landb. Hogesch. Wageningen 66:1-80

Adamse AD (1968) Bulking of Dairy Waste Activated Sludge. Water Res 2:715-722

Barnard JL (1978) Solving Sludge Bulking Problems. Wat Poll Contr $77: 103-106$
Curtis EJC (1969) Sewage Fungus: Its nature and effects. Wat Res 3:289-311

Dias FF, Dondero NC, Finstein MS (1968) Attached Growth of Sphaerotilus and Mixed Populations in a Continuous-flow Apparatus. Appl Microbiol 16:1191-1199

Favre J (1975) Inhibition de la respiration et de la croissance de Sphaerotilus natans par la lumière visible et UV-proche à forte intensité. Thèse, Juris-Verlag Zürich

Gaufin AR, Tarzwell CR (1956) Aquatic Macroinvertebrate Communities as Indicators of Organic Pollution in Lytle Creek. Sew Ind Wast 28:906-924

Gloor R, Leidner H (1976) Bestimmung von Carbonsäuren aus wässriger Lösung mittels Kapillar-Gas-Chromatographie. Chromatographia 9:618-623

Harrison ME, Heukelekian H (1958) Slime infestation. Literature Review. Sew Ind Wast 30:1278-1302

Heukelekian H, Ingols RS (1940) Studies on Activated Sludge Bulking. 2. Bulking Included by Domestic Sewage. Sewage Wks J 12:694-714

Mechsner K1, Wuhrmann K (1974) Ecological Considerations and an Examplification on Biological Treatment for Dairy Wastes. FIL-IDF. Ann Bull 77: 75-84

Mulder EG (1964) Iron Bacteria, Particularly those of the Sphaerotilus-Leptothrix Group and Industrial Problems. J appl Bact 27:151-173

Phaup JD (1968) The Biology of Sphaerotilus Species. Water Res 2:597-614

Pipes WO (1967) Bulking of Activated Sludge. Adv appl Microbiol 9:185-234

Roberts JC (1977) Sewage Fungus in Rivers Receiving Paper Mill Effluent. Water Res 11:603-610

Ruchoft CC, Kachmar JF (1941) Studies of Sewage Purification. XIV. The Role of Sphaerotilus natans in Activated Sludge Bulking. Pub. Health Rep 56:1727-1757

Ruchti J, Kunkler D (1966) Enzymatische Bestimmung von Glucose, Fructose and Saccharose in Gewässern. Schweiz Z Hydrol $28: 62-68$

Received May 10, 1983 